\title{
RNA silencing-related genes contribute to tolerance of infection with potato virus $X$ and $Y$ in a susceptible tomato plant
}

\author{
Joon Kwon ${ }^{1}$, Atsushi Kasai ${ }^{2}$, Tetsuo Maoka ${ }^{3}$, Chikara Masuta ${ }^{1,4}$, Teruo Sano ${ }^{2}$ and Kenji S. Nakahara ${ }^{1,4^{*}}$ (i)
}

\begin{abstract}
Background: In plants, the RNA silencing system functions as an antiviral defense mechanism following its induction with virus-derived double-stranded RNAs. This occurs through the action of RNA silencing components, including Dicer-like (DCL) nucleases, Argonaute (AGO) proteins, and RNA-dependent RNA polymerases (RDR). Plants encode multiple AGOs, DCLs, and RDRs. The functions of these components have been mainly examined in Arabidopsis thaliana and Nicotiana benthamiana. In this study, we investigated the roles of DCL2, DCL4, AGO2, AGO3 and RDR6 in tomato responses to viral infection. For this purpose, we used transgenic tomato plants (Solanum lycopersicum cv. Moneymaker), in which the expression of these genes were suppressed by double-stranded RNA-mediated RNA silencing.

Methods: We previously created multiple DCL (i.e., DCL2 and DCL4) (hpDCL2.4) and RDR6 (hpRDR6) knockdown transgenic tomato plants and here additionally did multiple AGO (i.e., AGO2 and AGO3) knockdown plants (hPAGO2.3), in which double-stranded RNAs cognate to these genes were expressed to induce RNA silencing to them. Potato virus $X(P V X)$ and $Y(P V Y)$ were inoculated onto these transgenic tomato plants, and the reactions of these plants to the viruses were investigated. In addition to observation of symptoms, viral coat protein and genomic RNA were detected by western and northern blotting and reverse transcription-polymerase chain reaction (RT-PCR). Host mRNA levels were investigated by quantitative RT-PCR.

Results: Following inoculation with PVX, hpDCL2.4 plants developed a more severe systemic mosaic with leaf curling compared with the other inoculated plants. Systemic necrosis was also observed in hpAGO2.3 plants. Despite the difference in the severity of symptoms, the accumulation of PVX coat protein (CP) and genomic RNA in the uninoculated upper leaves was not obviously different among hpDCL2.4, hpRDR6, and hpAGO2.3 plants and the empty vector-transformed plants. Moneymaker tomato plants were asymptomatic after infection with PVY. However, hpDCL2.4 plants inoculated with PVY developed symptoms, including leaf curling. Consistently, PVY CP was detected in the uninoculated symptomatic upper leaves of hpDCL2.4 plants through western blotting. Of note, PVY CP was rarely detected in other asymptomatic transgenic or wild-type plants. However, PVY was detected in the uninoculated upper leaves of all the inoculated plants using reverse transcription-polymerase chain reactions. These findings indicated that PVY systemically infected asymptomatic Moneymaker tomato plants at a low level (i.e., no detection of CP via western blotting).
\end{abstract}

*Correspondence: knakahar@res.agr.hokudai.ac.jp

${ }^{1}$ Graduate School of Agriculture, Hokkaido University, Sapporo, Hokkaido 060-8589, Japan

Full list of author information is available at the end of the article original author(s) and the source, provide a link to the Creative Commons licence, and indicate if changes were made. The images or other third party material in this article are included in the article's Creative Commons licence, unless indicated otherwise in a credit line to the material. If material is not included in the article's Creative Commons licence and your intended use is not permitted by statutory regulation or exceeds the permitted use, you will need to obtain permission directly from the copyright holder. To view a copy of this licence, visit http://creativecommons.org/licenses/by/4.0/. The Creative Commons Public Domain Dedication waiver (http://creativeco mmons.org/publicdomain/zero/1.0/) applies to the data made available in this article, unless otherwise stated in a credit line to the data. 
Conclusion: Our results indicate that the tomato cultivar Moneymaker is susceptible to PVX and shows mild mosaic symptoms, whereas it is tolerant and asymptomatic to systemic PVY infection with a low virus titer. In contrast, in hpDCL2.4 plants, PVX-induced symptoms became more severe and PVY infection caused symptoms. These results indicate that DCL2, DCL4, or both contribute to tolerance to infection with PVX and PVY. PVY CP and genomic RNA accumulated to a greater extent in DCL2.4-knockdown plants. Hence, the contribution of these DCLs to tolerance to infection with PVY is at least partly attributed to their roles in anti-viral RNA silencing, which controls the multiplication of PVY in tomato plants. The necrotic symptoms observed in the PVX-infected hpAGO2.3 plants suggest that AGO2, AGO3 or both are also distinctly involved in tolerance to infection with PVX.

Keywords: Dicer-like protein 2, Dicer-like protein 4, Argonaute 2, Argonaute 3, Potato virus X, Potato virus Y

\section{Background}

The plant RNA silencing-based defense enlists a complex set of proteins to combat intracellular parasites, including viruses, retrotransposons, and other highly repetitive genome elements [1]. This defense cascade is commonly triggered by intracellularly formed double-stranded RNA (dsRNA) or partially double-stranded stem-loop RNA. These are processed by Dicer-like (DCL) nucleases into small RNAs of discrete sizes (21-25 nucleotides [nt]), referred to as small interfering RNAs (siRNAs).

siRNAs are not the end product of the cascade. Rather, they are the sequence specificity determinants of RNAinduced silencing complexes (RISC), directing Argonaute (AGO) proteins in RISC to cellular RNA or DNA complementary to the siRNAs. This process silences corresponding genes or genetic elements through targeted cleavage, repression of translation, or DNA methylation $[2,3]$. In some eukaryotes, such as plants and fungi, cellular RNA-dependent RNA polymerase (RDR) acts to convert aberrant RNAs to dsRNA, leading to small RNA amplification and more intensive RNA silencing [4-6].

RNA viruses produce dsRNA as a replication intermediate, thus rendering them targets of RNA silencing [7]. DCL2 and DCL4 are largely responsible for processing viral dsRNAs into small pieces, termed virus-derived siRNAs (vsiRNAs), which can then be incorporated into RISC [8-15]. The resulting "aberrant" viral RNA cleavage products are thought to be substrates for plant RDR proteins, which subsequently generate more dsRNA [6]. The major contributors to the production of secondary vsiRNAs are RDR1, RDR2, and RDR6 [16]. Determining which AGO proteins are involved in defenses against RNA viruses has been the subject of a number of studies. In an in vitro assay, Arabidopsis AGO1, AGO2, AGO3, and AGO5 showed antivirus activity against a member of the genus Tombusvirus. In addition, specific AGOs (e.g., AGO1, AGO2, AGO3, AGO4, AGO5, and AGO9) were shown to selectively bind small RNAs derived from viroids or viruses [17-20]. These results suggest that multiple AGO proteins have the intrinsic ability to target viruses. Several AGO mutants were shown to increase susceptibility to viruses [21]; examples include AGO1 mutants and cucumber mosaic virus (CMV), turnip crinkle virus (TCV), and brome mosaic virus $[15,22-$ 24]; AGO4 mutants and tobacco rattle virus $[25,26]$; and an AGO7 mutant and TCV [15]. Among them, AGO2 appears to be a major player in RNA silencing against viruses and has been implicated in defense against $\mathrm{CMV}, \mathrm{TCV}$, tobacco rattle virus, potato virus $\mathrm{X}$ (PVX), turnip mosaic virus (TuMV), and tomato bushy stunt virus [20-28]. In addition, AGO5 appears to play a secondary antiviral role in the absence of AGO2 [10, 14]. Meanwhile, attenuated viruses with mutated virus silencing suppressors have also been used to identify plant factors involved in antiviral silencing, including DCL2, DCL4, AGO1, AGO2, DRB4, RDR1, RDR6, and HEN1 [6, 12, 16, 20, 27, 28]. The aforementioned studies have been mostly performed with Arabidopsis and Nicotiana benthamiana. Whether RNA silencingrelated genes have similar functions and roles in crop plants is worthy of investigation.

Potato virus $X$ is a type member of the genus Potexvirus (Alphaflexiviridae). Potato virus X (PVX) predominantly infects Solanaceous plants. Plants belonging to the Brassicaceae family are generally not considered to be hosts for PVX. Recent studies employing Arabidopsis thaliana revealed that RNA silencing is the chief determinant of the non-host immunity against PVX. Indeed, inactivation of DCLs (DCL2 and DCL4) or AGO2 enable PVX to efficiently infect $A$. thaliana plants $[9,23,29]$. Another study demonstrated that the full restriction of PVX requires AGO5 in addition to AGO2 [30].

Potato virus $Y$ is a type member of the genus Potyvirus, family Potyviridae [31]. Potato virus Y (PVY) is a flexuous rod-shaped virus; its genome consists of a single-strand positive sense RNA (length: $\sim 9.7 \mathrm{~kb}$ ), which contains two opening reading frames (ORFs) encoding 12 proteins. One large ORF encodes a polyprotein that is cleaved into 10 functional proteins. A second small ORF, located in the P3 cistron in a different frame, 
encodes a polypeptide termed PIPO (Pretty Interesting Potyviridae ORF). Two proteins (P3N-PIPO and P3NALT) are expressed through the RNA polymerase slippage mechanism in the P3 cistron [32-37].

The tomato (Solanum lycopersicum) is an important vegetable crop and a model plant for the research of fruit development and plant defenses [38], including virusderived/induced RNA silencing and plant systemic gene silencing. There are 7 DCLs (DCL1, 2a, 2b, 2c, 2d, 3 and 4), 15 AGOs (AGO1a, 1b, 2a, 2b, 3, 4a, 4b, 4c, 4d, 5, 6, 7, $10 \mathrm{a}, 10 \mathrm{~b}$ and 15), and 6 RDRs (RDR1, 2, 3a, 3b, 6a and 6b) encoded in the tomato genome [39]. An analysis of tomato DCL1 and DCL3-silencing mutants indicated that DCL1 produces canonical miRNAs and a few 21-nt siRNAs [40], while DCL3 is involved in the biosynthesis of heterochromatic 24-nt siRNAs and long miRNAs [41]. DCL4 is required for the production of 21-nt tasiRNAs that in turn target the ARFs to alter tomato leaf development [42]. Numerous DCL2 genes (i.e., DCL2a, DCL2b, DCL2c, and DCL2d) are encoded in tomato [39]. Recently, the DCL2b-dependent miRNA pathway in tomato was shown to affect susceptibility to PVX and TMV [43]. DCL2b is also required for the biosynthesis of 22-nt small RNAs to defend against ToMV [44].

In this study, we examine the virulence of PVX and PVY in transgenic tomato plants, in which the expression of the DCL2, DCL4, AGO2, AGO3 and RDR6 genes was suppressed. Our aim in this study was to investigate whether these RNA silencing-related genes are involved in tolerance or defense against infection with these viruses in a crop plant.

\section{Materials and methods Plants and viruses}

Wild-type tomato (Solanum lycopersicum cv. Moneymaker) and transgenic tomato plants created from Moneymaker were used in this study. DCL2 and DCL4- and RDR6-repressed (hpDCL2.4 and hpRDR6) tomato plants were previously created using the host RNA silencing mechanism $[45,46]$. Tomato plants with AGO2a, AGO2b and AGO3 (Solyc02G069260, Solyc02G069270, and Solyc02G096280, registered in the tomato genome database at https://solgenomics.net/organism/Solan um_lycopersicum/genome) repressed (hpAGO2.3) were created in the same manner as hpDCL2.4 tomato plants [45]. The inverted repeat (IR) sequences were constructed by placing parts of AGO2, AGO3 (947 bp) in a head-tohead orientation across an intron sequence to create an IR sequence (Fig. 1a). The IR sequences were cloned into the BglII/KpnI site of the binary vector pIG121-Hm [45] downstream of the CaMV-35S promoter and introduced into Agrobacterium tumefaciens strain EHA105 to transform the tomato plants. T3-generation plants were used in this study. In addition, tomato plants transformed with pIG121-Hm containing an empty cassette were created and used as a negative control (empty vector). PVX derived from the infectious clone $\mathrm{pP} 2 \mathrm{C} 2 \mathrm{~S}$, which was constructed with the PVX-UK3 strain [47], as well as the $\mathrm{N}$ [48] and $\mathrm{O}\left[49\right.$ ] strains of PVY $\left(\mathrm{PVY}^{\mathrm{N}}\right.$ and $\left.\mathrm{PVY}^{\mathrm{O}}\right)$ were used for the inoculation tests in this study.

\section{Plant growth conditions and viral infection}

Tomato plants were cultivated in a growth room at 21-23 ${ }^{\circ} \mathrm{C}$ with a $16-\mathrm{h}$ photoperiod. PVX- and PVYinfected leaf discs $(50 \mathrm{mg})$ were ground in inoculation buffer (0.1 M phosphate buffer [pH 7.0], 1\% 2-mercaptoethanol). The crude sap was mechanically inoculated onto the first and second leaves of 2-week old tomato plants. At the same time, other plants were inoculated with inoculation buffer alone as a control (mock inoculation). Three plants of each transgenic and wild-type were inoculated with these viruses and analyzed.

\section{Reverse transcription-polymerase chain reaction (RT-PCR) and real-time PCR}

PVY genomic RNA was detected using RT-PCR as follows. Tomato leaves were ground in liquid nitrogen, and total RNA was extracted with TRIzol ${ }^{\mathrm{TM}}$ Reagent (Thermo Fisher Scientific, Inc., Waltham, MA, USA). All RNA samples were treated with RNase-free DNase I (Roche Diagnostics, Basel, Switzerland). cDNA was synthesized from $1 \mu \mathrm{g}$ of RNA extract using the modified Moloney Murine Leukemia Virus (MMLV) reverse transcriptase ReverTra Ace ${ }^{\circledR}$ (Toyobo, Osaka, Japan). PCR was performed to detect viral genomic RNA and endogenous mRNA. The mixture $(25 \mu \mathrm{l})$ contained cDNA corresponding to $0.1 \mu \mathrm{g}$ RNA, $0.4 \mu \mathrm{M}$ of each of the specific primer pairs (Additional file 1: Table S1), $0.2 \mathrm{mM}$ deoxyribonucleotide triphosphate (dNTPs), and $0.625 \mathrm{U} \mathrm{Ex}$ $\mathrm{Taq}^{\mathrm{TM}}$ DNA polymerase (Takara, Otsu, Siga, Japan). PCR mixtures were incubated for $2 \mathrm{~min}$ at $94{ }^{\circ} \mathrm{C}$, followed by 28 cycles at $94{ }^{\circ} \mathrm{C}$ for $30 \mathrm{~s}, 60{ }^{\circ} \mathrm{C}$ for $30 \mathrm{~s}$, and $72{ }^{\circ} \mathrm{C}$ for $60 \mathrm{~s}$. The PCR products were fractionated through $1.2 \%$ agarose gel electrophoresis. Quantitative PCR (qPCR) was performed using the AriaMx real-time PCR system (Agilent Technologies, Santa Clara, CA, USA). The reaction mixture $(25 \mu \mathrm{l})$ contained $0.3 \mathrm{mM}$ (each) forward and reverse primers (Additional file 1: Table S1) $0.2 \mathrm{mM}$ dNTPs, 0.625 U Ex Taq ${ }^{\text {TM }}$ DNA polymerase (Takara), SYBR Green (1/800 dilution) (Thermo Fisher Scientific), and CDNA obtained by reverse transcribing $50 \mathrm{ng}$ of total RNA. Samples were incubated for $2 \mathrm{~min}$ at $95^{\circ} \mathrm{C}$, followed by 39 cycles at $95^{\circ} \mathrm{C}$ for $10 \mathrm{~s}$, and at $58^{\circ} \mathrm{C}$ and $72{ }^{\circ} \mathrm{C}$ for $20 \mathrm{~s}$ each. 


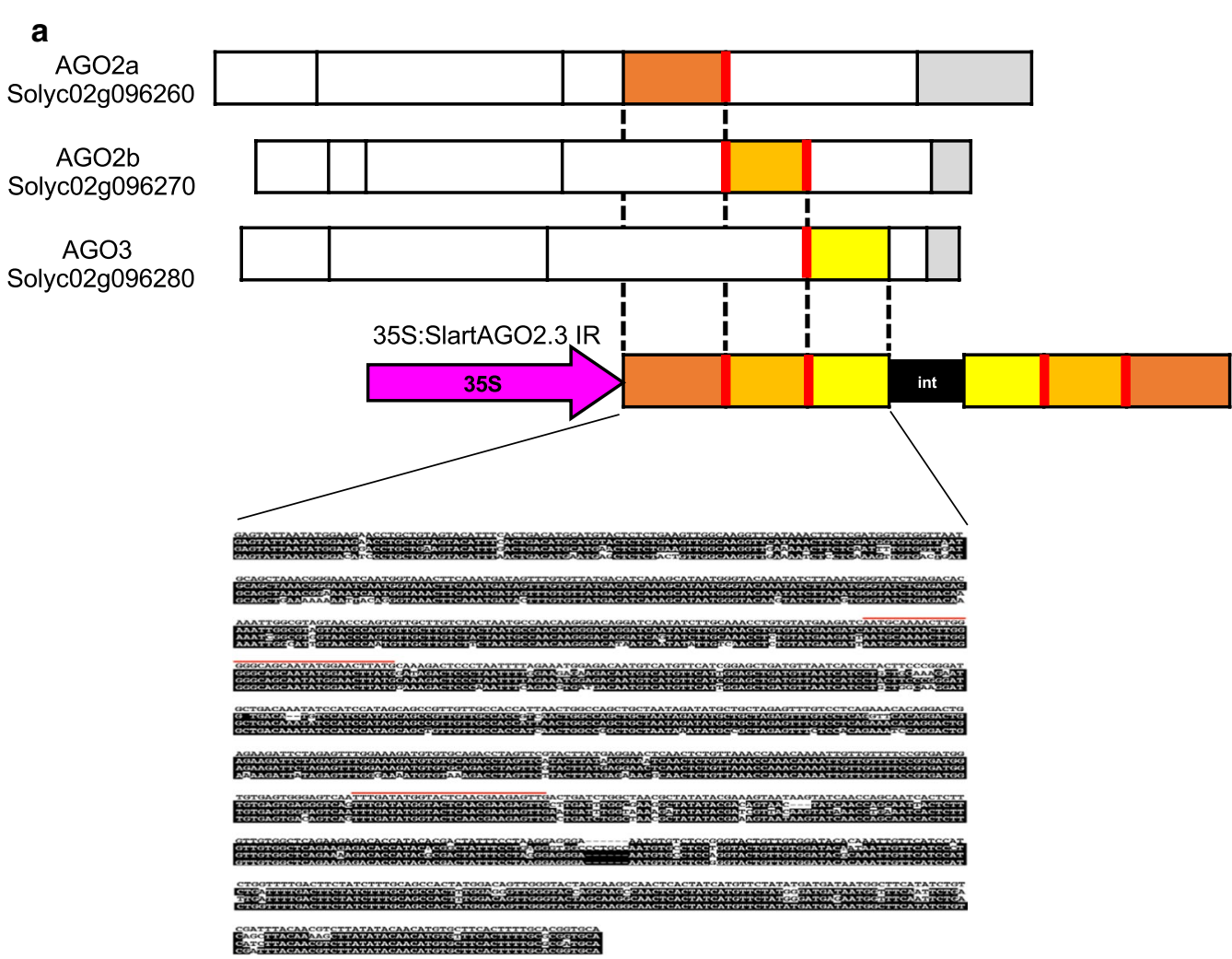

b

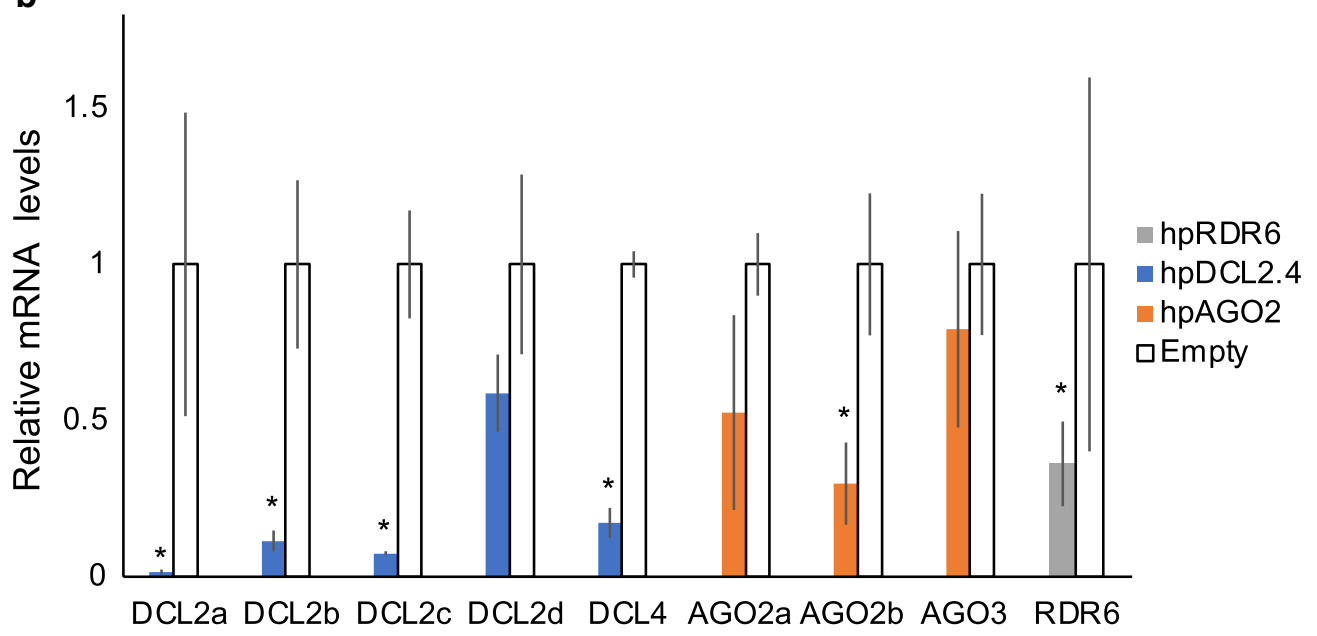

Fig. 1 a Schematic diagram of the artificial chimeric genes ( $A G O 2$ and 3). Based on the alignment of the sequences of three tomato AGO genes ( $A G O 2 a$, b and AGO3) registered in the database, three regions in AGO, i.e., one from AGO2a (270 bp), one from AGO2b (283 bp), and one from AGO3 (295 bp) were selected. The chimeric gene constructs were subsequently placed in head-to-head orientation across an intron sequence ('int' in the figure) to create an IR sequence. b Relative expression levels of the DCLs, AGOs, and RDR6 mRNAs in transgenic S. lycopersicum plants expressing dsRNAs, compared with empty vector-transformed plants. The relative levels of these mRNAs were investigated through real-time reverse transcription-polymerase chain reaction (RT-PCR) using $18 \mathrm{~S}$ ribosome RNA as a control. Error bars represent SE. Student's t-test was applied to analyze the data, comparing dsRNA-expressing and empty vector-transformed plants. The assay was repeated twice, and each analysis consisted of three biological replicates from three plants per treatment. Asterisks indicate a statistically significant difference in the accumulation of gene mRNA between plants with or without the expression of dsRNA $(p<0.05)$ 


\section{Northern and western blotting assays}

Accumulation of the PVX and PVY CP and genomic RNA was investigated through western and northern blotting as previously described [50]. Upper uninoculated leaves from each plant at 15, 20, 25, and 30 days post-inoculation (dpi) were harvested and total RNA preparations $(1-10 \mu \mathrm{g})$ were extracted using the TRIzol $^{\mathrm{TM}}$ Reagent. After denaturing the RNA extracts by heating at $65{ }^{\circ} \mathrm{C}$ for $15 \mathrm{~min}$ in a solution containing RNA denaturation buffer ( $0.9 \mathrm{M}$ disodium phosphate, $0.1 \mathrm{M}$ monosodium phosphate, $37 \%$ formaldehyde, $0.05 \%$ formamide), the samples were loaded into $1.4 \%$ agarose gels containing $5 \%$ formaldehyde and $1 \times 3-(\mathrm{N}$-morpholino) propanesulfonic acid buffer and run at $100 \mathrm{~V}$ for $30 \mathrm{~min}$. Following transfer to a nylon membrane (Hybond-N; GE Healthcare, Chicago, IL, USA), hybridization with a digoxigenin-labeled probe (Roche Diagnostics) was performed to detect the 3 '-terminal regions of PVX genome segments. Chemiluminescence signals with CDP-star (Millipore Sigma, St. Louis, MO, USA) were quantitatively detected using a LAS-4000 mini-imaging system (GE Healthcare).

Western blotting was conducted as previously described [51]. Total proteins were separated through electrophoresis in $12 \%$ sodium dodecyl sulfate-polyacrylamide gel electrophoresis Bis-Tris gels using Tris-glycine buffer, followed by electrotransfer onto a polyvinylidene difluoride membrane. For the detection of viral coat proteins, primary antibodies raised against PVX and PVY CP, provided by Japan Plant Protection Association, were used at a 1:1000 dilution, while alkaline phosphatase-conjugated goat antirabbit immunoglobulin G (Thermo Fisher Scientific) was used as the secondary antibody. Chemiluminescence signals were detected using the CDP-Star reagent in a LAS-4000 mini-imaging system.

\section{Results \\ DCL2, DCL4 and AGO2 are involved in tolerance to PVX infections in tomato}

We initially confirmed repression of the expression levels of DCL2, DCL4, AGO2, and RDR6 in hpDCL2.4, hpAGO2.3, and hpRDR6 plants through real-time RTPCR. There was no significant difference in the expression levels of the DCL2d in hpDCL2.4 plants with those detected in empty-vector transgenic plants (Fig. 1b). In addition, the expression levels of DCL2a, b, c and DCL4 were also decreased to approximately $3 \%, 10 \%, 8 \%$ and $15 \%$, respectively, in transgenic tomato plants compared with empty vector transformed plants. In hpAGO2.3 and hpRDR6 plants, the expression levels of both AGO2b and RDR6 genes were decreased to approximately $29 \%$ and $36 \%$ of the wild-type levels. In contrast, the expression levels of the AGO2a and b were not altered significantly in hpAGO2.3 plants. We inoculated these transgenic tomato plants with PVX and observed symptoms in non-inoculated upper leaves of all inoculated plants at 5 dpi (Fig. 2, Table 1). The symptoms that developed in hpDCL2.4 and hpAGO2.3 were more severe than those that developed in hpRDR6 and control transgenic plants with the empty vector. Specifically, necrotic spots began to develop in hpAGO2.3 plants on the second upper leaf from the inoculated leaf at $5 \mathrm{dpi}$, and the necrotic symptoms spread systemically at 20 dpi (Fig. 2). More severe dwarfing, as well as mosaics and leaf-malformation were observed in the hpDCL2.4 plants (Fig. 2). We investigated the accumulation of PVX CP and genomic RNA through western blotting and northern blotting (Fig. 3a, b) to determine whether the difference in symptoms was associated with the multiplication of PVX in these plants. The three transgenic tomato plants (i.e., hpDCL2.4, hpAGO2.3, hpRDR6) inoculated and those with the empty vector (Empty) all accumulated $\mathrm{CP}$ and the full-length genomic RNA comparably at $15 \mathrm{dpi}$ (Fig. 3b). Of note, the accumulation of subgenomic RNAs differed among samples. The levels of DCLs, AGOs, and RDR6 mRNAs in transgenic lines infected with PVX were investigated by RT-qPCR (Fig. 3c). The levels of DCL2a, DCL2c, and DCL4 mRNAs in the hpDCL2.4 line infected with PVX were lower than those of the healthy empty vector-transformed plants. Unexpectedly, the mRNA levels of DCL2a, DCL2b, DCL2c, and DCL4 were also reduced in PVX-infected empty vector-transformed plants. In contrast, the mRNA levels of DCL2b and DCL2d were increased in PVX-infected hpDCL2.4 and empty vector-transformed plants. In hpAGO2.3 and hpRDR6 plants infected with PVX, the mRNA levels of AGO2, AGO3, and RDR6 were similar to those of PVXinfected and healthy empty vector-transformed plants.

\section{DCL2 and DCL4 are required for defense against infection with PVY}

Subsequently, we mechanically inoculated $\mathrm{PVY}^{\mathrm{N}}$ into hpDCL2.4, hpAGO2.3, and hpRDR6 plants. Symptoms were only observed on the non-inoculated upper leaves of hpDCL2.4 (Fig. 4, Table 1), suggesting systemic infection of hpDCL2.4 plants with $\mathrm{PVY}^{\mathrm{N}}$. PVY ${ }^{\mathrm{N}}$ $\mathrm{CP}$ and genomic RNA were detected through western blotting and RT-PCR to confirm the systemic infection of hPDCL2.4 and to examine whether the other inoculated plants had latent systemic infections of $\mathrm{PVY}^{\mathrm{N}}$. PVY CP was detected via western blotting only in DCL2.4 plants, which exclusively showed symptoms (Fig. 5a). PVY genomic RNA was detected through RT-PCR in all the inoculated plants at $15 \mathrm{dpi}$ under 30 cycles of amplification. However, after 20 cycles of amplification, 


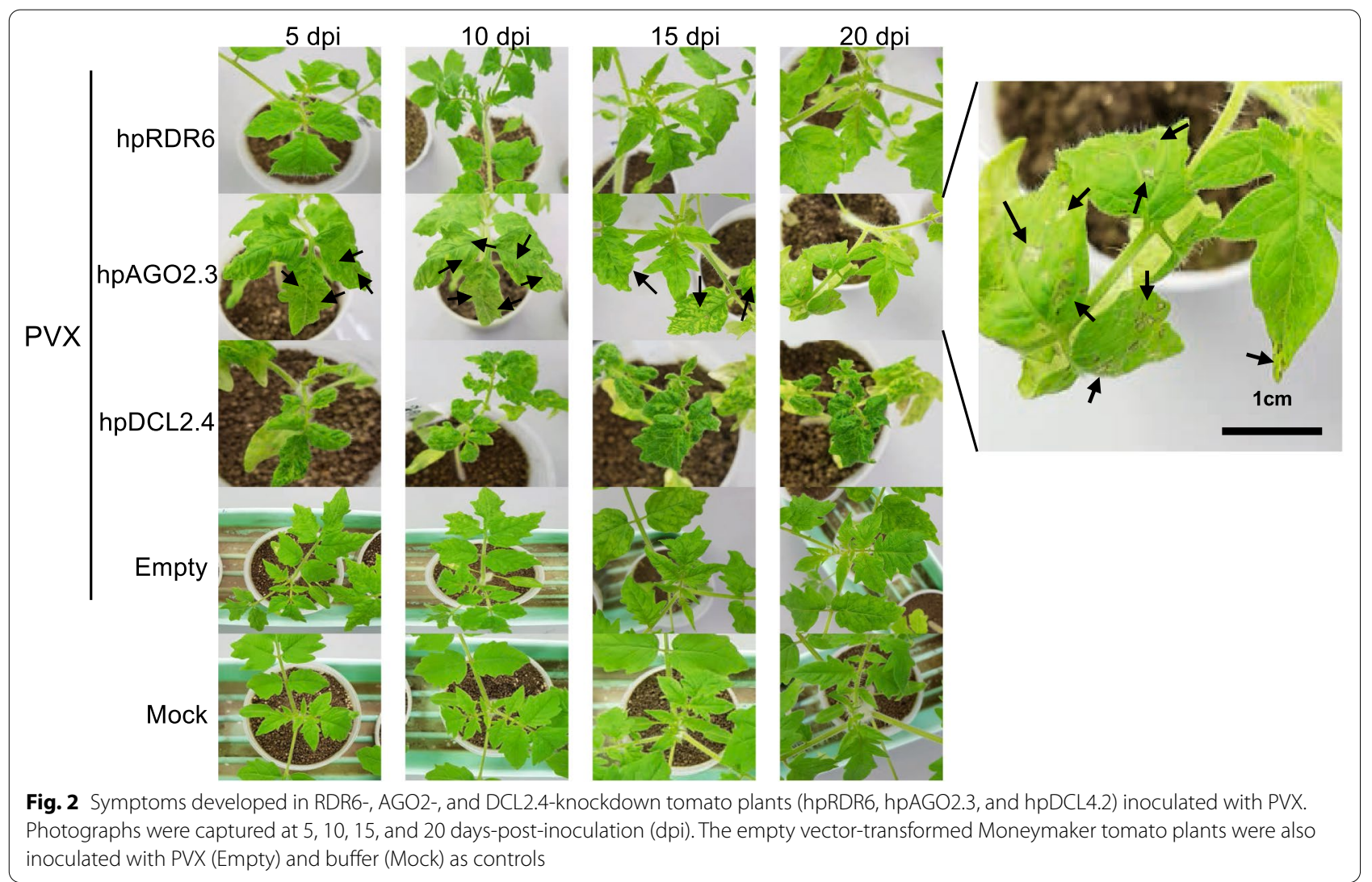

\section{Table 1 Reaction of transgenic plants following mechanical inoculation with PVX-UK3 and PVYN strains}

\begin{tabular}{lllll}
\hline Host plants & \multicolumn{4}{l}{ Symptoms on leaves } \\
\cline { 2 - 5 } & $\mathbf{5} \mathbf{d p i}$ & $\mathbf{1 0} \mathbf{d p i}$ & $\mathbf{1 5} \mathbf{d p i}$ & $\mathbf{2 0} \mathbf{d p i}$ \\
\hline PVX-inoculated & & & & \\
hpDCL2.4 & $-/ \mathrm{M}, \mathrm{Mal}$ & $-/ \mathrm{M}, \mathrm{Mal}$ & $-/ \mathrm{M}, \mathrm{Mal}$ & $-/ \mathrm{M}, \mathrm{Mal}$ \\
hpRDR6 & $-/ \mathrm{M}$ & $-/ \mathrm{M}$ & $-/ \mathrm{M}$ & $-/ \mathrm{M}$ \\
hpAGO2.3 & $-/ \mathrm{M}, \mathrm{NS}$ & $-/ \mathrm{M}, \mathrm{NS}$ & $-/ \mathrm{M}, \mathrm{NS}$ & $-/ \mathrm{M}, \mathrm{NS}$ \\
Empty & $-/ \mathrm{M}$ & $-/ \mathrm{M}$ & $-/ \mathrm{M}$ & $-/ \mathrm{M}$ \\
Mock & $-/-$ & $-/-$ & $-/-$ & $-/-$ \\
PVYN-inoculated & & & & \\
hpDCL2.4 & $-/-$ & $-/-$ & $-/ \mathrm{mM}, \mathrm{Mal}$ & $-/ \mathrm{M}, \mathrm{LC}$ \\
hpRDR6 & $-/-$ & $-/-$ & $-/-$ & $-/-$ \\
hpAGO2.3 & $-/-$ & $-/-$ & $-/-$ & $-/-$ \\
Empty & $-/-$ & $-/-$ & $-/-$ & $-/-$ \\
Mock & $-/-$ & $-/-$ & $-/-$ & $-/-$ \\
\hline
\end{tabular}

a Inoculated leaves/upper leaves; Lc, leaf curling; M, mosaic; mM, mild mosaic; NS, necrotic spot; Mal, malformation; $Y$, yellowing; -, symptomless or latent infection it was detected only in hpDCL2.4 plants (Fig. 5b). RTqPCR detected a reduction of the mRNA levels of all tested genes in $\mathrm{PVY}^{\mathrm{N}}$-infected hpDCL2.4, hpAGO2.3, and hpRDR6 plants compared with those measures in $\mathrm{PVY}^{\mathrm{N}}$-infected empty vector-transformed plants. However, the mRNA levels of DCL2d, AGO2a, and RDR6 in PVY-infected empty vector-transformed plants were unexpectedly lower than those observed in PVY-infected hpDCL2.4, hpAGO2.3, and hpRDR6 plants.

We further inoculated the parental cultivar and hpDCL2.4 plants with both $\mathrm{PVY}^{\mathrm{N}}$ and $\mathrm{PVY}^{\mathrm{O}}$, and compared their susceptibility to the viruses (Table 2). This experiment was performed to rule out the possibility that stresses during the production of transgenic plants affect their susceptibility to $\mathrm{PVY}^{\mathrm{N}}$ and $\mathrm{PVY}^{\mathrm{O}}$ in a strain-specific manner. As expected, hpDCL2.4 plants inoculated with both strains showed symptoms; however, none of the inoculated parental cultivar plants developed symptoms (Table 2). In addition, PVY CP was detected using western blotting only in hpDCL2.4 plants inoculated with both PVYs (Fig. 6) though PVY CP was observed in PVYinoculated Moneymaker cultivar at 40dpi (Fig. 6). PVY genomic RNA was detected in all the samples from both PVY-inoculated plants through RT-PCR at $20 \mathrm{dpi}$ and in the following days. However, at $15 \mathrm{dpi}$, PVY genomic 


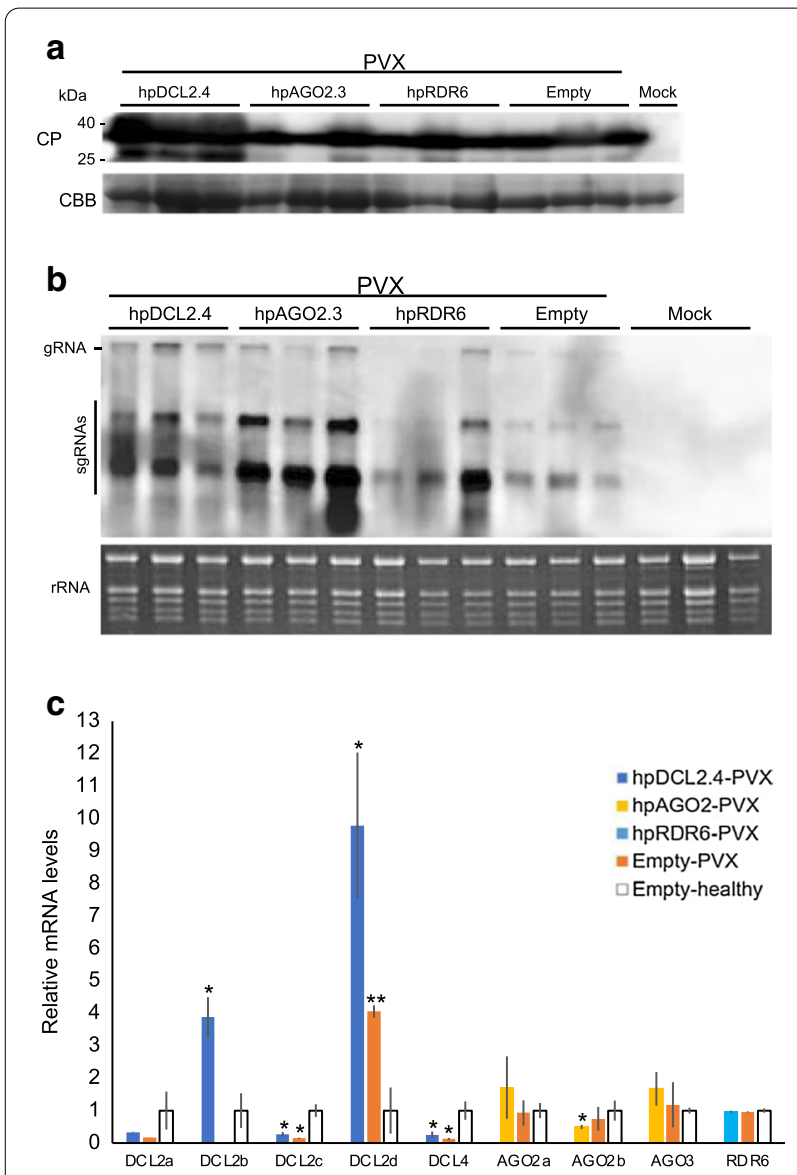

Fig. 3 Detection of PVX CP and genomic RNA in tomato plants inoculated with PVX using western (a) and northern blotting (b). a Total protein samples were prepared from non-inoculated upper leaves of RDR6-, AGO2-, and DCL2.4-knockdown tomato plants (hpRDR6, hpAGO2.3, and hpDCL4.2) at $15 \mathrm{dpi}$. Samples were also prepared from the empty vector-transformed plants inoculated with PVX (Empty) and buffer (Mock) as controls. The CBB-stained gel was used as a loading control (RUBISCO protein). b Total RNAs extracted from hpRDR6, hpAGO2.3, hpDCL2.4, Empty, and Mock plants at 15 dpi were fractionated using an agarose gel to detect PVX genomic (gRNA) and subgenomic RNAs (sgRNAs) in non-inoculated upper leaves through northern blotting. rRNA was used as loading control. c RT-qPCR to compare the DCL2s, DCL4, AGO2, AGO3, and RDR6 mRNA in the upper leaves of hpDCL2.4, hpAGO2.3, hpRDR6, and empty vector-transformed plants infected with PVX (Empty-PVX) with the levels measured in healthy empty vector-transformed plants (Empty-healthy) at 15 dpi. 18S ribosome RNA was used as a control. Error bars represent SE. Student's t-test was applied to analyze the data. Each analysis was performed with three biological replicates; data were collected from three plants of each knockdown and empty vector-transformed transgenic lines. The values with the double asterisk $\left({ }^{* *} p<0.01\right)$ and single asterisk $\left({ }^{*} p<0.05\right)$ were statistically significant at the $1 \%$ and $5 \%$ levels, respectively, compared with those of healthy empty vector-transformed plants
RNA was only clearly detected in the samples obtained from hpDCL2.4 (Fig. 6). These results indicate that PVY latently and systemically infects the Moneymaker cultivar. Moreover, silencing of DCL2 and DCL4 increases the accumulation of PVY CP and genomic RNA, resulting in the development of symptoms.

\section{Discussion}

Silencing the DCL and AGO genes altered the reactions of a susceptible tomato plant to infection with PVX and PVY. The symptoms of PVX infection were exacerbated in DCL2, DCL4, AGO2 and AGO3-knockdown transgenic tomato plants. We observed more severe dwarfing and leaf deformation in hpDCL2.4, more severe mosaics in hpDCL2.4 and necrotic systems in hpAGO2.3 plants, compared with those in the PVX-inoculated other transgenic and wild-type plants. On the other hand, infection with PVY caused symptoms only in hpDCL2.4-knockdown plants, but not in the other transgenic or wild-type plants. RT-PCR tests showed that all PVY-inoculated plants were systemically infected with PVY, indicating that the tomato cultivar Moneymaker is susceptible to infection with PVX and PVY. These results suggest that DCL2, DCL4, AGO2 and AGO3 are involved in tolerance to infection with PVX and PVY in a susceptible tomato plant. Note that, considering the significantly increased levels of DCL2b and DCL2d mRNA in PVX-infected hpDCL2.4 plants, more severe symptoms are not necessarily caused by the downregulation of the DCL genes in plants. The higher levels of these DCL mRNAs may be attributed to the activation of their transcription [5254], as well as the suppression of RNA silencing by PVX infection, and miR6026, which is produced by and targets DCL2s [43].

DCL2, DCL4, AGO2 and AGO3 are important factors in the RNA silencing-mediated antiviral defense $[12,15,20,27,33,55]$. Therefore, it is likely that these factors contribute to tolerance through their roles in antiviral RNA silencing. This would be the case for the tolerance to infection of two strains of PVY (i.e., $\mathrm{PVY}^{\mathrm{N}}$ and $\mathrm{PVY}^{\mathrm{O}}$ ), involving DCL2 and DCL4. Western blotting was only able to detect PVY CP in inoculated hpDCL2.4 plants though it detected PVY CP at 40 dpi. RT-PCR consistently detected PVY genomic RNA in lower PCR cycle numbers and time-course experiments in samples from inoculated hpDCL2.4 plants, although all inoculated plants were systemically infected with PVY. There results indicate that the higher accumulation of PVY observed in hpDCL2.4 plants can probably be attributed to the reduced activity of RNA silencing against PVY. DCL proteins possess RNase III activity to generate small RNAs, such as siRNAs and microRNAs (miRNAs) [55], and silencing or mutations in DCLs would affect siRNA 


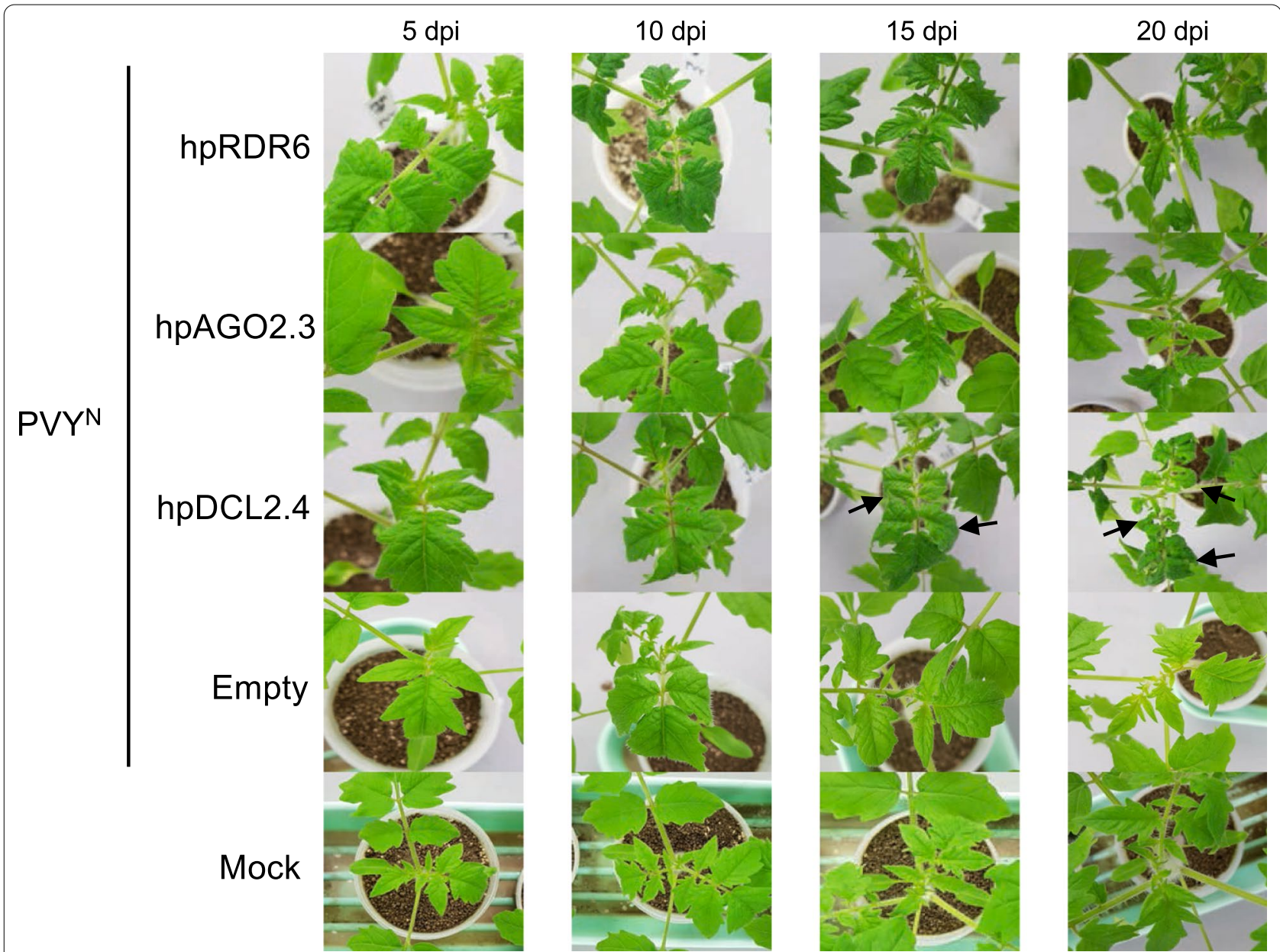

Fig. 4 Symptoms developed in RDR6-, AGO2-, and DCL2.4-knockdown tomato plants (hpRDR6, hpAGO2.3, and hpDCL4.2) inoculated with PVYN . Photographs were captured at 5, 10, 15, and 20 dpi. The empty vector-transformed Moneymaker tomato plants were also inoculated with PVYN (Empty) and buffer (Mock) as controls

biogenesis. We recently showed a defect in the biogenesis of siRNAs, especially $22 \mathrm{nt}$ siRNAs, derived from viroid RNA in hpDCL2.4 plants infected with the potato spindle tuber viroid [44]. Studies have reported the increased accumulation of CMV genomic RNAs [12] and increased susceptibility to PVX and the TuMV helper componentprotease mutant in Arabidopsis DCL double (DCL2 and 4) and triple mutants (DCL2, 3, and 4) [56]. Increased accumulation of TuMV and CMV genomic RNAs was observed in DCL2- and DCL4-knockdown N. benthamiana [56]. Silencing of DCL4 facilitates the systemic movement of Zucchini yellow mosaic virus in $N$. benthamiana [54]. These studies indicate that DCL2 and DCL4 restrict the multiplication of viruses in susceptible plants. In this study, tomato DCL2 and DCL4 also did not completely prevent infection with PVY. However, they efficiently restricted infection to reduce the occurrence of symptoms in a susceptible cultivar.
Tolerance to infection with PVX does not appear to be attributed to the roles of DCL2, DCL4, and AGO2 in antiviral RNA silencing. This conclusion was based on the absence of obvious difference in $\mathrm{CP}$ and genomic RNA levels among hpDCL2.4, hpAGO2.3 transgenic and wild-type tomato plants (Fig. 4a). PVX has a relatively weak RNA silencing suppressor, triple gene block protein 1 (TGBp1) [57], and may have ability to escape or survive under active conditions of antiviral RNA silencing [58]. This ability may partly explain the absence of an obvious increase in PVX accumulation in DCL2.4 and AGO2 plants (Fig. 4b). RNA silencing is one of the major antiviral defense mechanisms involved in the regulation of numerous endogenous genes via siRNAs and miRNAs [59]. Thus, symptom exacerbations may be attributed to differences in the expression of endogenous genes via the knockdown of DCL2, DCL4, AGO2 and AGO3. We recently showed that symptom exacerbations 


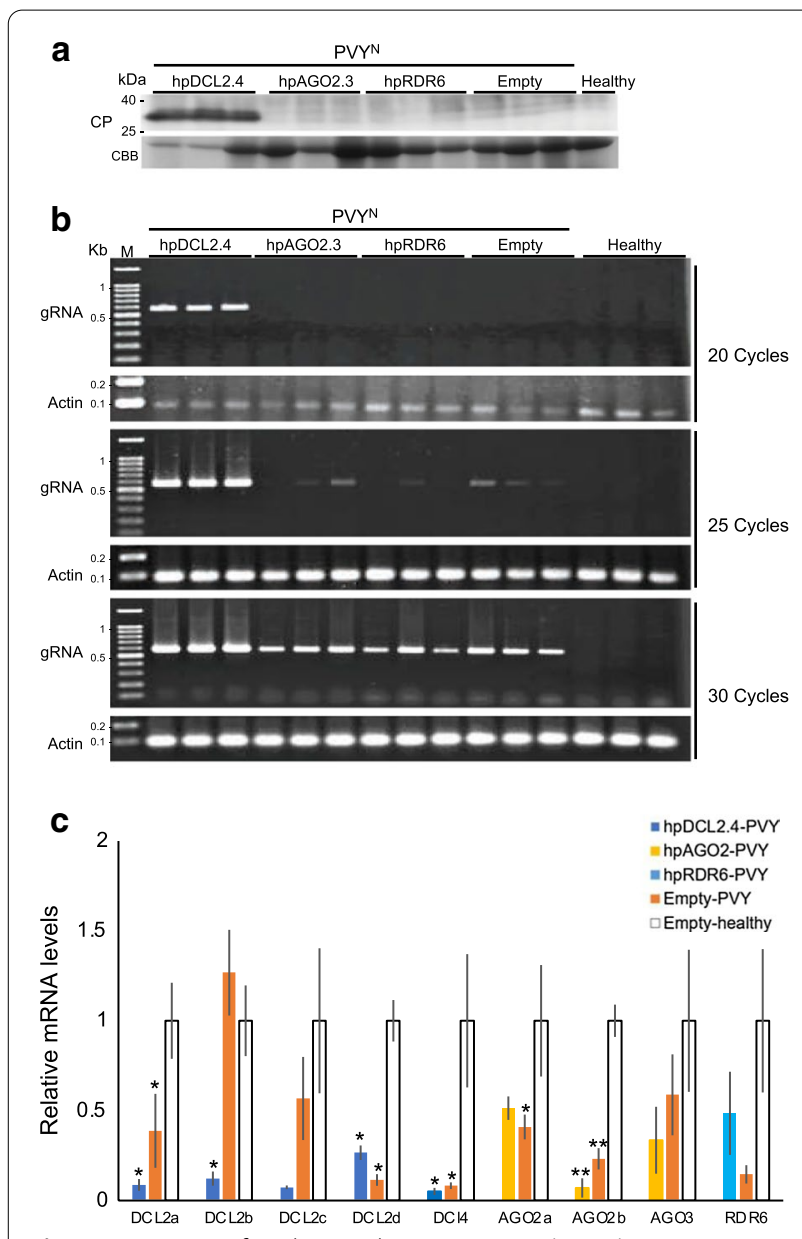

Fig. 5 Detection of viral $C P$ and genomic RNA (gRNA) in tomato plants inoculated with $P Y^{N}$. a For the detection of $C P$, total protein was extracted from the upper leaves of RDR6-, AGO2-, and DCL2.4-knockdown tomato plants (hpRDR6, hpAGO2.3, and hpDCL4.2) at $15 \mathrm{dpi}$. The CBB-stained gel was used as a loading control. $\mathbf{b}$ Semi-quantitative RT-PCR for the levels of PVYN genomic RNA in non-inoculated upper leaves of hpRDR6, hpAGO2.3, and hpDCL4.2 at $15 \mathrm{dpi}$. Their PCR products at 20,25, and 30 cycles were fractionated using agarose gels. The actin gene was used as a control. c RT-qPCR to compare the DCL2s, DCL4, AGO2, AGO3, and RDR6 mRNA in the upper leaves of hpDCL2.4, hpAGO2.3, hpRDR6, and empty vector-transformed plants infected with PVY (Empty-PVY) with the levels detected in healthy empty vector-transformed plants (Empty-healthy) at $15 \mathrm{dpi}$. $18 \mathrm{~S}$ ribosome RNA was used as control. Error bars represent SE. Student's t-test was applied to analyze the data. Each analysis was performed with three biological replicates; data were collected from three plants of each knockdown and empty vector-transformed transgenic lines. The values with the double asterisk $\left({ }^{* *} p<0.01\right)$ and single asterisk $\left({ }^{*} p<0.05\right)$ were statistically significant at the $1 \%$ and $5 \%$ levels, respectively, compared with those of healthy empty vector-transformed plants

in hpDCL2.4 plants infected with potato spindle tuber viroid could be attributed to the increased expression of miR398a-3p, which increased the production of reactive oxygen species [44].
Table 2 Reactions of transgenic plants following mechanical inoculation with $\mathrm{PVY}^{\mathrm{N}}$ and $\mathrm{PVY}^{\mathrm{O}}$ strains

\begin{tabular}{lllll}
\hline Host plants & \multicolumn{4}{l}{ Symptoms on leaves } \\
\cline { 2 - 5 } & $\mathbf{5} \mathbf{d p i}$ & $\mathbf{1 0} \mathbf{d p i}$ & $\mathbf{1 5} \mathbf{~ d p i}$ & $\mathbf{2 0} \mathbf{~ d p i}$ \\
\hline PVYN-inoculated & & $-/-$ & $-/ \mathrm{mM}, \mathrm{Mol}$ & $-/ \mathrm{mM}, \mathrm{Mol}$ \\
hpDCL2.4 & $-/-$ & $-/-$ & $-/-$ & $-/-$ \\
Moneymaker & $-/-$ & $-/-$ & $-/-$ & $-/-$ \\
Healthy control & $-/-$ & - & & \\
PVY-inoculated & & $-/ \mathrm{mM}, \mathrm{Mol}$ & $-/ \mathrm{mM}, \mathrm{Mol}$ & $-/ \mathrm{mM}, \mathrm{Mol}$ \\
hpDCL2.4 & $-/ \mathrm{mM}, \mathrm{Mol}$ & $-/-$ & $-/-$ & $-/-$ \\
Moneymaker & $-/-$ & $-/-$ & $-/-$ & $-/-$ \\
Healthy control & $-/-$ & $-/-$ &
\end{tabular}

a Inoculated leaves/upper leaves; Lc, leaf curling; $M$, mosaic; Mol, mottling; $m M$, mild mosaic; NS, necrotic spot; Mal, malformation; $Y$, yellowing; -, symptomless or latent infection

Interactions between PVX and AGO2 have previously been studied. Similar symptom exacerbations, including systemic necrosis, have been observed in the AGO2knockout $N$. benthamiana using CRISPR/Cas9 [60]. The Arabidopsis Col-0 plant is a non-host for PVX; however, PVX becomes capable of multiplication in inoculated leaves following mutation of AGO2 [23]. P25, also known as triple gene block protein 1 (TGBp1), suppresses RNA silencing [61, 62], which can be partly explained by P25 binding to and directing the degradation of AGO1 via the $26 \mathrm{~S}$ proteasome [63]. Studies have shown that P25 has an affinity for AGO2 [23, 63]. On the other hand, necrosis or cell death associated with infection with PVX or closely related viruses that belong to the genus Potexvirus has been reported. Infection with PVX triggers hypersensitive cell death responses in potato plants carrying the $\mathrm{Nb}$ gene, and P25 is the elicitor of these responses [64]. TGBp3 induces the unfolded protein response during infection with PVX. This effect is important in the regulation of cellular cytotoxicity that could otherwise lead to cell death if the viral proteins reach high levels in the ER $[65,66]$. An isolate of the plantago asiatica mosaic virus causes systemic necrosis in N. benthamiana, and its RNA-dependent RNA polymerase is a virulence determinant for necrotic symptoms [67]. Additionally, an isolate of the PVX-OS strain induced systemic necrotic mosaic in Nicotiana spp, and the 1422 amino acid C-terminal of its RNA-dependent RNA polymerase is a determinant of systemic necrotic mosaic symptoms [68]. Co-infection with PVX and PVY causes systemic necrosis in tobacco plants, and PVX P25 and PVY helper component-protease have been identified as determinants for necrotic symptoms [69]. Recently, systemic necrosis was correlated with an enhanced expression of lipoxygenase 


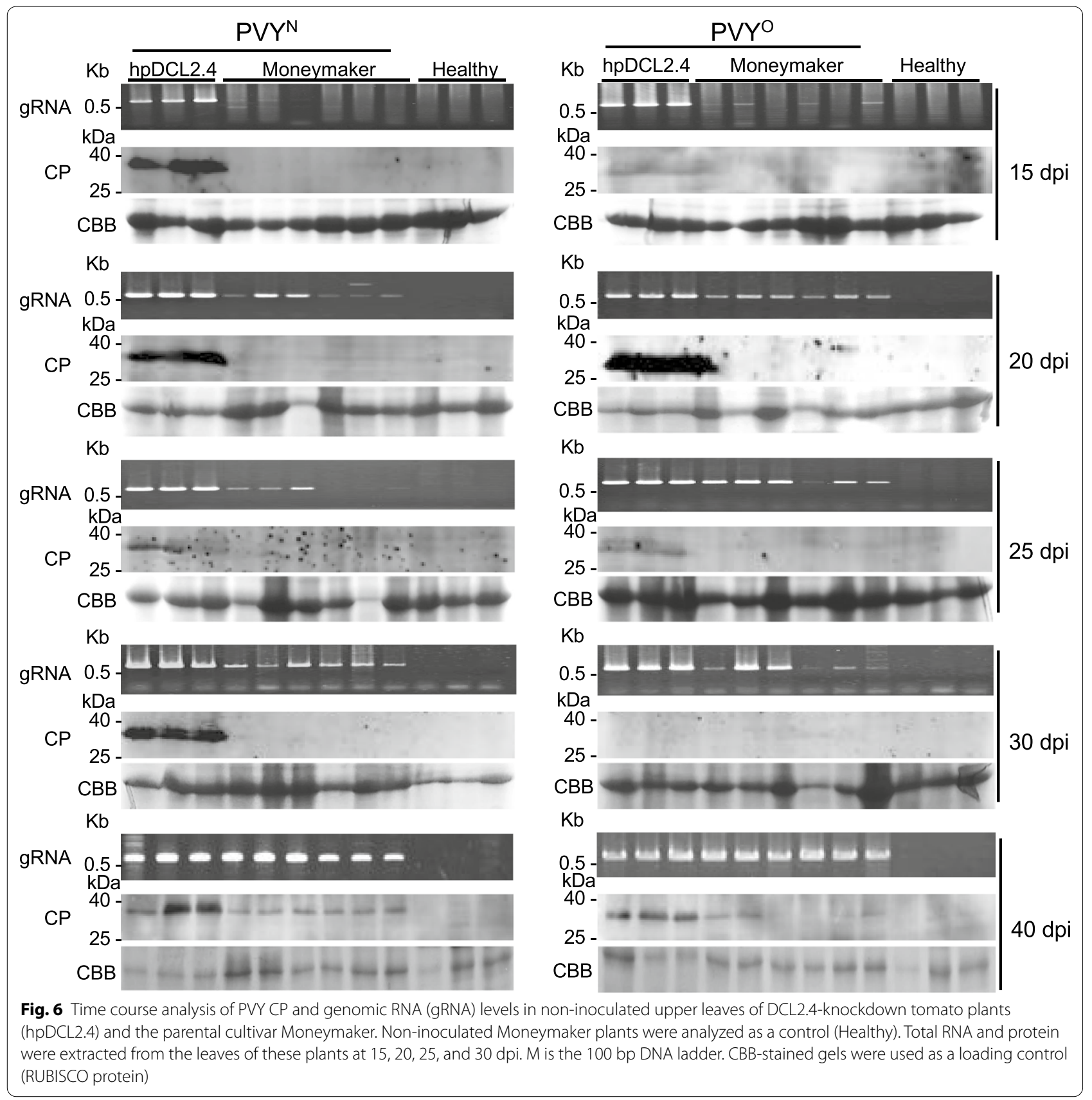

activity in PVX and PVY co-infected plants [70]. Lipoxygenase acts on polyunsaturated fatty acid substrates in the first step of the biosynthetic pathway of jasmonic acid, a hormone involved in the execution of hypersensitive response cell death in tobacco [71]. Downregulation of double-stranded-RNA-Binding Protein (DRB2) by VIGS is able to reduce PVX-triggered systemic necrosis in ago2 mutant $N$. benthamiana [72].

These previous studies may help reveal the mechanism through which AGO2-knockdown alters the expression of endogenous genes and which host and viral genes involved in the development of necrotic symptoms during infection with PVX.

\section{Conclusion}

In this study, we observed an increased accumulation of PVY CP and genomic RNA with symptoms in hpDCL2.4 plants, suggesting that DCL2 and DCL4 are involved in anti-PVY defense in tomato plants via the RNA silencing mechanism. Although all the PVX-inoculated transgenic 
plants comparably accumulated $\mathrm{CP}$ and genomic RNA, more severe and additional necrotic symptoms were observed in hpDCL2.4 and hpAGO2.3 plants. Based on the present findings, DCL2, DCL4 and AGO2 are involved in tolerance to infection with PVX and PVY in tomato.

\section{Supplementary information}

Supplementary information accompanies this paper at https://doi. org/10.1186/s12985-020-01414-x.

Additional file 1: Table S1. Primers used for CDNA amplification and qRT-PCR

\section{Abbreviations}

AGO: Argonaute; CMV: cucumber mosaic virus; CP: coat protein; CRISPR: clustered regularly interspaced short palindromic repeats; DCL: Dicer-like; DIG: digoxigenin; dpi: days post inoculation; DRB: double-stranded RNA binding; ER: endoplasmic reticulum; HEN: HUA ENHANCER; HR: hypersensitive response; IR: inverted repeat; miRNA: microRNA; ORF: opening reading frames; PIPO: Pretty Interesting Potyviridae ORF; PVX: potato virus X; PVY: potato virus $Y$; RISC: RNA-induced silencing complexes; RT-PCR: reverse transcription-polymerase chain reaction; siRNA: small interfering RNA; TCV: turnip crinkle virus; TuMV: turnip mosaic virus; TGB: triple gene block; vsiRNA: virus-derived siRNA.

\section{Acknowledgements}

We would like to thank Uni-edit (https://uni-edit.net/) for editing and proofreading this manuscript.

\section{Authors' contributions}

JK and KSN wrote the manuscript and JK, CM and KSN designed the experiments. JK and AK performed the experiments. JK, TM, CM, TS and KSN analyzed and discussed the data. All authors read and approved the final manuscript.

\section{Funding}

This work was supported by the Japan Society for the Promotion of Science KAKENHI (16H04879, 15H04455, and 18H0221).

\section{Availability of data and materials}

The datasets used during the current study are available from the corresponding author with an appropriate request.

\section{Ethics approval and consent to participate}

Not applicable.

\section{Consent for publication}

Not applicable.

\section{Competing interests}

The authors declare that they have no competing interest.

\section{Author details}

${ }^{1}$ Graduate School of Agriculture, Hokkaido University, Sapporo, Hokkaido 060-8589, Japan. ${ }^{2}$ Faculty of Agriculture and Life Science, Hirosaki University, Hirosaki 036-8561, Japan. ${ }^{3}$ Division of Agro-Environmental Research, Hokkaido Agricultural Research Center, NARO, Sapporo, Hokkaido 062-8555, Japan. ${ }^{4}$ Research Faculty of Agriculture, Hokkaido University, Sapporo, Hokkaido 060-8589, Japan.

Received: 30 January 2020 Accepted: 18 September 2020

Published online: 08 October 2020

\section{References}

1. Ding SW, Voinnet O. Antiviral immunity directed by small RNAs. Cell. 2007;130:413426

2. Calarco JP, Martienssen RA. Genome reprogramming and small interfering RNA in the Arabidopsis germline. Curr Opin Genet Dev. 2011;21:134-9.

3. Chen X. Small RNAs — secrets and surprises of the genome. Plant J. 2010;61:941-58.

4. Cogoni C, Macino G. Gene silencing in Neurospora crassa requires a protein homologous to RNA-dependent RNA polymerase. Nature. 1999;399:166-9.

5. Dalmay T, Hamilton A, Rudd S, Angell S, Baulcombe DC. An RNA-dependent RNA polymerase gene in Arabidopsis is required for posttranscriptional gene silencing mediated by a transgene but not by a virus. Cell. 2000;101:543-53.

6. Wang XB, Wu Q, Ito T, Cillo F, Li WX, Chen X, Yu JL, Ding SW. RNAimediated viral immunity requires amplification of virus-derived siRNAs in Arabidopsis thaliana. Proc Natl Acad Sci USA. 2010;107:484-9.

7. Xie Z, Johansen LK, Gustafson AM, Kasschau KD, Lellis AD, Zilberman D, Jacobsen SE, Carrington JC. Genetic and functional diversification of small RNA pathways in plants. PLoS Biol 2004:2:e104.

8. Bouché N, Lauressergues D, Gasciolli V, Vaucheret H. An antagonistic function for Arabidopsis DCL2 in development and a new function for DCL4 in generating viral siRNAs. EMBO J. 2006;25:3347-56.

9. Andika IB, Maruyama K, Sun L, Kondo H, Tamada T, Suzuki N. Differential contributions of plant Dicer-like proteins to antiviral defences against Potato virus X in leaves and roots. Plant J. 2015a;81:781-93.

10. Brosseau C, Moffett P. Functional and genetic analysis identify a role for Arabidopsis ARGONAUTE5 in antiviral RNA silencing. Plant Cell. 2015a:27:1742-54.

11. Deleris A, Gallego-Bartolome J, Bao J, Kasschau KD, Carrington JC, Voinnet O. Hierarchical action and inhibition of plant Dicer-like proteins in antiviral defense. Science. 2006;313:68-71.

12. Diaz-Pendon JA, Li F, Li WX, Ding SW. Suppression of antiviral silencing by Cucumber mosaic virus $2 \mathrm{~b}$ protein in Arabidopsis is associated with drastically reduced accumulation of three classes of viral small interfering RNAs. Plant Cell. 2007;19:2053-63.

13. Dunoyer P, Himber C, Ruiz-Ferrer V, Alioua A, Voinnet O. Intra- and intercellular RNA interference in Arabidopsis thaliana requires components of the microRNA and heterochromatic silencing pathways. Nat Genet. 2007;39:848-56.

14. Garcia-Ruiz H, Carbonell A, Hoyer JS, Fahlgren N, Gilbert KB, Takeda A, Giampetruzzi A, Garcia Ruiz MT, McGinn MG, Lowery N, Martinez Baladejo MT, Carrington JC. Roles and programming of Arabidopsis ARGONAUTE proteins during turnip mosaic virus infection. PLoS Pathog. 2015;11:e1004755.

15. Qu F, Ye X, Morris TJ. Arabidopsis DRB4, AGO1, AGO7, and RDR6 participate in a DCL4-initiated antiviral RNA silencing pathway negatively regulated by DCL1. Proc Natl Acad Sci USA. 2008;105:14732-7.

16. Zhang $C$, Wu Z, Li Y, Wu J. Biogenesis, function, and applications of virusderived small RNAs in plants. Front Microbiol. 2015a;6:1237.

17. Minoia S, Carbonell A, Di Serio F, Gisel A, Carrington JC, Navarro B, Flores R. Specific argonautes selectively bind small RNAs derived from Potato Spindle Tuber Viroid and Attenuate Viroid accumulation in vivo. J Virol. 2014;88:11933-45.

18. Schuck J, Gursinsky T, Pantaleo V, Burgyán J, Behrens SE. AGO/RISC-mediated antiviral RNA silencing in a plant in vitro system. Nucleic Acids Res. 2013:41:5090-103.

19. Takeda A, Iwasaki S, Watanabe T, Utsumi M, Watanabe Y. The mechanism selecting the guide strand from small RNA duplexes is different among Argonaute proteins. Plant Cell Physiol. 2008;49:493-500.

20. Wang XB, Jovel J, Udomporn P, Wang Y, Wu Q, Li WX, Gasciolli V, Vaucheret $H$, Ding SW. The 21-nucleotide, but not 22-nucleotide, viral secondary small interfering RNAs direct potent antiviral defense by two cooperative Argonautes in Arabidopsis thaliana. Plant Cell. 2011;23:1625-38.

21. Carbonell A, Carrington JC. Antiviral roles of plant ARGONAUTES. Curr Opin Plant Biol. 2015;27:111-7.

22. Harvey JJ, Lewsey MG, Patel K, Westwood J, Heimstädt S, Carr JP, Baulcombe DC. An antiviral defense role of AGO2 in plants. PLOS ONE. 2011;6:e14639. 
23. Jaubert M, Bhattacharjee S, Mello AF, Perry KL, Moffett P. ARGONAUTE2 mediates RNA-silencing antiviral defenses against Potato virus $X$ in arabidopsis. Plant Physiol. 2011;156:1556-64.

24. Ma X, Nicole MC, Meteignier LV, Hong N, Wang G, Moffett P. Different roles for RNA silencing and RNA processing components in virus recovery and virus-induced gene silencing in plants. J Exp Bot. 2015;66:919-32.

25. Odokonyero D, Mendoza MR, Alvarado VY, Zhang J, Wang X, Scholtho HB. Transgenic down-regulation of ARGONAUTE2 expression in Nicotiana benthamiana interferes with several layers of antiviral defenses. Virology. 2015:486:209-18

26. Fernández-Calvino L, Martínez-Priego L, Szabo EZ, Guzmán-Benito I, González I, Canto T, Lakatos L, Llave C. Tobacco rattle virus 16K silencing suppressor binds ARGONAUTE 4 and inhibits formation of RNA silencing complexes. J Gen Virol. 2016;97:246-57.

27. Scholthof HB, Alvarado VY, Vega-Arreguin JC, Ciomperlik J, Odokonyero D, Brosseau C, Jaubert M, Zamora A, Moffett P. Identification of an ARGONAUTE for antiviral RNA silencing in Nicotiana benthamiana. Plant Physiol. 2015:156:1548-55.

28. Zhang C, Wu Z, LiY, Wu J. Biogenesis, function, and applications of virusderived small RNAs in plants. Front Microbiol. 2015b:6:1237.

29. Andika IB, Maruyama K, Sun L, Kondo H, Tamada T, Suzuki N. Different Dicer-like protein components required for intracellular and systemic antiviral silencing in Arabidopsis thaliana. Plant Signal Behav. 2015b;10:e1039214.

30. Brosseau C, Moffett P. Functional and genetic analysis identify a role for Arabidopsis ARGONAUTE5 in antiviral RNA silencing. Plant Cell. 2015b;27:1742-54.

31. Plisson C, Drucker M, Blanc S, German-Retana S, Le Gall O, Thomas D, Bron P. Structural characterization of HC-Pro, a plant virus multifunctional protein. J Biol Chem. 2003;278:23753-61.

32. Karasev AV, Gray SM. Continuous and emerging challenges of potato virus Y in potato. Annu Rev Phytopathol. 2013;51:571-86.

33. Riechmann JL, Laín S, García JA. Highlights and prospects of potyvirus molecular biology. J Gen Virol. 1992;73:1-16.

34. Chung BYW, Miller WA, Atkins JF, Firth AE. An overlapping essential gene in the Potyviridae. Proc Natl Acad Sci USA. 2008;105:5897-902.

35. Olspert A, Chung BYW, Atkins JF, Carr JP, Firth AE. Transcriptional slippage in the positive-sense RNA virus family Potyviridae. EMBO Rep. 2015;16:995-1004.

36. Wylie SJ, Adams M, Chalam C, Kreuze J, López-Moya JJ, Ohshima K, Zerbini FM. ICTV virus taxonomy profile: Potyviridae. J Gen Virol. 2017:98:352.

37. Komoda YH, Choi SH, Sato M, Atsumi G, Abe J, Fukuda J, Honjo MN, Nagano AJ, Komoda K, Nakahara KS, Uyeda I. Truncated yet functional viral protein produced via RNA polymerase slippage implies underestimated coding capacity of RNA viruses. Sci Rep UK. 2016;6:21411.

38. Bergougnoux $\bigvee$. The history of tomato: from domestication to biopharming. Biotechnol Adv. 2014;32:170-89.

39. Bai M, Yang GS, Chen WT, Mao ZC, Kang HX, Chen GH, Yang YH, Xie BY. Genome-wide identification of Dicer-like, Argonaute and RNAdependent RNA polymerase gene families and their expression analyses in response to viral infection and abiotic stresses in Solanum lycopersicum. Gene. 2012;501:52-62.

40. Kravchik M, Sunkar R, Damodharan S, Stav R, Zohar M, Isaacson T, Arazi T. Global and local perturbation of the tomato microRNA pathway by a trans-activated DICER-LIKE 1 mutant. J Exp Bot. 2014;65:725-39.

41. Kravchik M, Damodharan S, Stav R, Arazi T. Characterization of a tomato DCL3-silencing mutant. Plant Sci. 2014;221:81-9.

42. Yifhar T, Pekker I, Peled D, Friedlander G, Pistunov A, Sabban M, Eshed $Y$. Failure of the tomato trans-acting short interfering RNA program to regulate AUXIN RESPONSE FACTOR3 and ARF4 underlies the wiry leaf syndrome. Plant Cell. 2012;24:3575-89.

43. Wang Z, Hardcastle TJ, Pastor AC, Yip WH, Tang S, Baulcombe DC. A novel DCL2-dependent miRNA pathway in tomato affects susceptibility to RNA viruses. Gene Dev. 2018;32:1155-60.

44. Wang T, Deng Z, Zhang X, Wang H, Wang Y, Liu X, Liu S, Xu F, Li T, Fu D, Shu B, Luo Y, Zhu H. Tomato DCL2b is required for the biosynthesis of 22-nt small RNAs, the resulting secondary siRNAs, and the host defense against ToMV. Hortic Res. 2018;5:1-14.

45. Suzuki T, Ikeda S, Kasai A, Taneda A, Fujibayashi M, Sugawara K, Sano T. RNAi-mediated down-regulation of Dicer-like 2 and 4 changes the response of 'Moneymaker' tomato to potato spindle tuber viroid infection from tolerance to lethal systemic necrosis, accompanied by up-regulation of miR398, 398a-3p and production of excessive amount of reactive oxygen species. Viruses. 2019;11:344

46. Naoi T, Kitabayashi S, Kasai A, Sugawara K, Adkar-Purushothama CR, Senda M, Hataya T, Sano T. Suppression of RNA-dependent RNA polymerase 6 in tomatoes allows potato spindle tuber viroid to invade basa part but not apical part including pluripotent stem cells of shoot apical meristem. PLoS ONE. 2020;15:e0236481.

47. Chapman S, Kavanagh T, Baulcombe DC. Potato virus $X$ as a vector for gene expression in plants. Plant J. 1992;2:549-57.

48. Ohki T, Sano M, Asano K, Nakayama T, Maoka T. Effect of temperature on resistance to Potato virus $Y$ in potato cultivars carrying the resistance

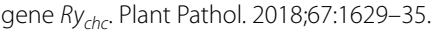

49. Masuta C, Nishimura M, Morishita H, Hataya T. A single amino acid change in viral genome-associated protein of potato virus $Y$ correlates with resistance breaking in 'Virgin A Mutant' tobacco. Phytopathology. 1999:89:118-23.

50. Jeon EJ, Tadamura K, Murakami T, Inaba JI, Kim BM, Sato M, Nakahara KS. rgs-CaM detects and counteracts viral RNA silencing suppressors in plant immune priming. J Virol. 2017;91:e00761-e817.

51. Nakahara KS, Masuta C, Yamada S, Shimura H, Kashihara Y, Wada TS, Sekiguchi T. Tobacco calmodulin-like protein provides secondary defense by binding to and directing degradation of virus RNA silencing suppressors. Proc Natl Acad Sci USA. 2012;109:10113-8.

52. Silva TF, Romanel EA, Andrade RR, Farinelli L, Østerås M, Deluen C, Vaslin MF. Profile of small interfering RNAs from cotton plants infected with the polerovirus Cotton leafroll dwarf virus. BMC Mol Biol. 2011;12:40.

53. Campos L, Granell P, Tárraga S, López-Gresa P, Conejero V, Bellés JM, Lisón P. Salicylic acid and gentisic acid induce RNA silencing-related genes and plant resistance to RNA pathogens. Plant Physiol Biochem. 2014;77:35-43.

54. Cordero T, Cerdán L, Carbonell A, Katsarou K, Kalantidis K, Daròs JA. Dicer-Like 4 Is involved in restricting the systemic movement of Zucchini yellow mosaic virus in Nicotiana benthamiana. Mol Plant Microbe Interact. 2017;30:63-71.

55. Vazquez F. Arabidopsis endogenous small RNAs: highways and byways. Trends Plant Sci. 2006;11:460-8.

56. Garcia-Ruiz H, Takeda A, Chapman EJ, Sullivan CM, Fahlgren N, Brempelis KJ, Carrington JC. Arabidopsis RNA-dependent RNA polymerases and Dicer-like proteins in antiviral defense and small interfering RNA biogenesis during turnip mosaic virus infection. Plant Cell. 2010;22:481-96.

57. Senshu H, Ozeki J, Komatsu K, Hashimoto M, Hatada K, Aoyama M, Namba S. Variability in the level of RNA silencing suppression caused by triple gene block protein 1 (TGBp1) from various potexviruses during infection. J Gen Virol. 2009;90:1014-24.

58. Van Wezel R, Hong Y. Virus survival of RNA silencing without deploying protein-mediated suppression in Nicotiana benthamiana. FEBS Lett. 2004;562:65-70.

59. Csorba T, Pantaleo V, Burgyán J. RNA silencing: an antiviral mechanism. Adv Virus Res. 2009;75:35-71.

60. Ludman M, Burgyán J, Fátyol K. Crispr/Cas9 mediated inactivation of argonaute 2 reveals its differential involvement in antiviral responses. Sci Rep UK. 2017;7:1-12.

61. Verchot-Lubicz J, Ye CM, Bamunusinghe D. Molecular biology of potexviruses: recent advances. J Gen Virol. 2007:88:1643-55.

62. Voinnet $\mathrm{O}$, Lederer C, Baulcombe DC. A viral movement protein prevents spread of the gene silencing signal in Nicotiana benthamiana. Cell. 2000;103:157-67.

63. Cho SK, Ryu MY, Shah P, Poulsen CP, Yang SW. Post-translational regulation of miRNA pathway components, AGO1 and HYL1, in plants. Mol Cells. 2016:39:581.

64. Malcuit I, Marano MR, Kavanagh TA, De Jong W, Forsyth A, Baulcombe DC. The 25-kDa movement protein of PVX elicits $n b$-mediated hypersensitive cell death in potato. Mol Plant Microbe Interact. 1999:12:536-43.

65. Ye C, Dickman MB, Whitham SA, Payton M, Verchot J. The Unfolded protein response is triggered by a plant viral movement protein. Plant Physiol. 2011;156:741-55

66. Lu Y, Yin M, Wang X, Chen B, Yang X, Peng J, MacFarlane S. The unfolded protein response and programmed cell death are induced by expression of Garlic virus X p11 in Nicotiana benthamiana. J Gen Virol. 2016:97:1462-8. 
67. Ozeki J, Takahashi S, Komatsu K, Kagiwada S, Yamashita K, Mori T, Namba S. A single amino acid in the RNA-dependent RNA polymerase of Plantago asiatica mosaic virus contributes to systemic necrosis. Arch Virol. 2006;151:2067-75.

68. Kagiwada S, Yamaji Y, Komatsu K, Takahashi S, Mori T, Hirata H, Suzuki M, Ugaki M, Namba S. A single amino acid residue of RNA-dependent RNA polymerase in the potato virus $X$ genome determines the symptoms in Nicotiana plants. Virus Res. 2005;110:177-82.

69. Pacheco R, García-Marcos A, Barajas D, Martiáñez J, Tenllado F. PVX—potyvirus synergistic infections differentially alter microRNA accumulation in Nicotiana benthamiana. Virus Res. 2012;165:231-5.

70. García-Marcos A, Pacheco R, Manzano A, Aguilar E, Tenllado F. Oxylipin biosynthesis genes positively regulate programmed cell death during compatible infections with the synergistic pair Potato virus X-Potato virus $Y$ and Tomato spotted wilt virus. J Virol. 2013;87:5769-73.

71. Montillet JL, Chamnongpol S, Rusterucci C, Dat J, van de Cotte B, Agnel JP, Battesti C, Inze D, Van Breusegem F, Triantaphylides C. Fatty acid hydroperoxides and $\mathrm{H}_{2} \mathrm{O}_{2}$ in the execution of hypersensitive cell death in tobacco leaves. Plant Physiol. 2005;138:1516-26.

72. Fátyol K, Fekete KA, Ludman M. Double-stranded-RNA-binding protein 2 participates in antiviral defense. J Virol. 2020;94:11.

\section{Publisher's Note}

Springer Nature remains neutral with regard to jurisdictional claims in published maps and institutional affiliations.
Ready to submit your research? Choose BMC and benefit from:

- fast, convenient online submission

- thorough peer review by experienced researchers in your field

- rapid publication on acceptance

- support for research data, including large and complex data types

- gold Open Access which fosters wider collaboration and increased citations

- maximum visibility for your research: over 100M website views per year

At BMC, research is always in progress.

Learn more biomedcentral.com/submissions 